\title{
FORUM
}

\section{WHAT MIGHT HAVE BEEN}

\section{Lt Col A. G. Johnson*}

One of the most intriguing of mental pastimes is to ponder on what the result might have been if certain famous happenings had been reversed. For example, if the Spanish Armada had succeeded in its task; or if Hertzog had been successful in his revolt of 1914, but two happenings in quite recent history, both originated by Winston Churchill, make a fascinating study. In 1915, as First Lord of the Admiralty and a member of the War Cabinet, he persuaded his colleagues to stage an invasion of Turkey with a view to opening the Dardenelles and so linking up with Russia. This failed. In 1941 as Prime Minister and Minister of Defence, as soon as Germany invaded Russia, he proclaimed the latter an ally and promised her all the support and help the British Empire could give until victory was achieved. This succeeded.

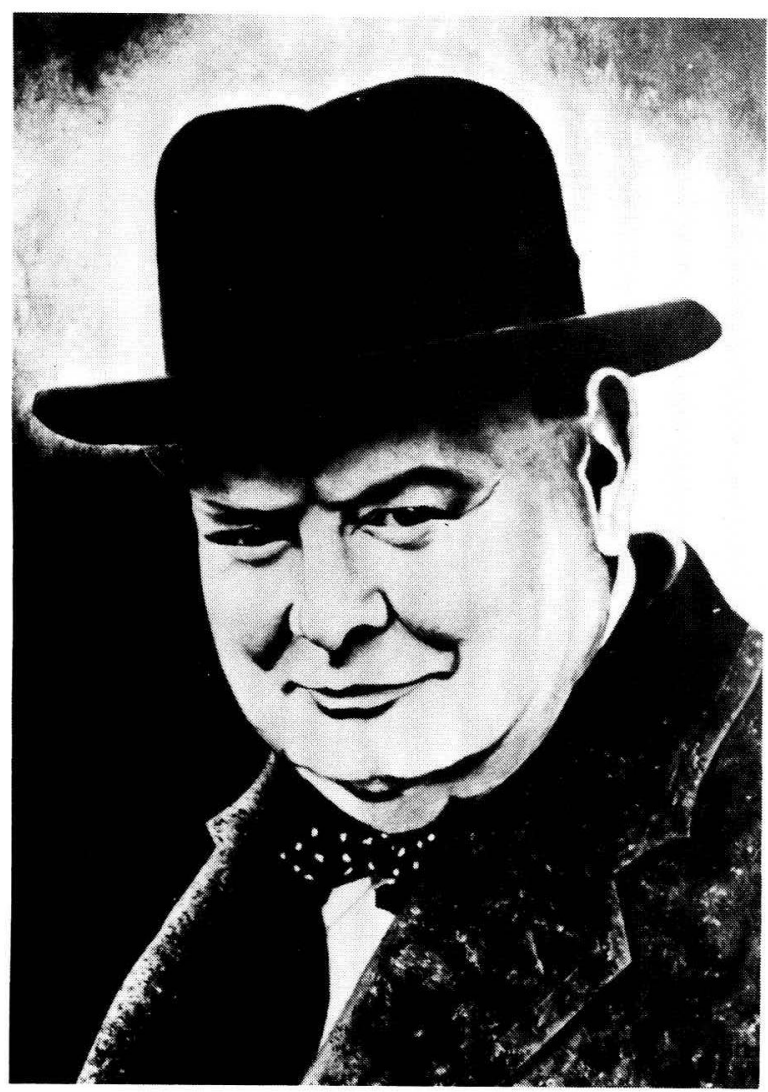

Winston Churchill, originated two happenings, in 1915 and in 1941 which gave rise to this fascinating forum article by Lt Col A. G. Johnson.
Now let us consider these two conceptions, their actuality and then their 'might have been'.

Of all the 'combined operations' carried out by British forces, that at Gallipoli was possibly the worst ever staged for the Turks knew, from the haphazard way in which preparations were made, what was intended. First, the attempt to force the Straits by the combined Anglo-French fleets. This failing, came weeks of long range shelling of the same area by the guns of the battleships. Then the preparation of bases on the Greek Islands the accumulation of troops, stores, shipping etc at Alexandria and Malta. Security was farcical. It was a prime example of how not to stage a surprise invasion. As a result, the whole campaign failed with the loss of thousands of lives. Ere victory was achieved over Turkey in the autumn of 1918 the cost in men and material was enormous, the troops suffering severely, especially through sickness, apart from the loss of one whole British army surrounded and forced to surrender at Kut el Amara.

Winston Churchill, instigator of the Gallipoli plan, was forced to resign from the Government and went to command a battalion in France. He took the blame for the defeat, all the 'pundits', not least Lord Kitchener with his hatred of what he called 'side shows', saying he had been wrong in his idea. But was he? Let us contemplate what might have been.

The landing on Gallipoli, carefully planned and mounted, succeeded. The Anzacs and British after some days of bitter fighting made good their hold on the Peninsular, and forced their way over the hilly spine of Gallipoli until they and their guns commanded the Dardenelles. Under their cover, minesweepers entered the Straits, quickly destroying the nets and minefields laid therein, so that the Allied fleet could pass through the Dardenelles into the Sea of Marmora, taking with it transports laden with troops and supplies. Thus threatened by landing on both flanks well to their rear, the Turkish armies retreated up the Peninsular offering but little resistance to the Allied forces closely following.

With their retreat, and the threat to Constantinople 
(as Istanbul was then called) from the allied fleets in the Sea of Marmora, the remembrance of old hatreds came to the help of the Allies. It was barely two years since the end of the Second Balken War and 'revenge is sweet'. Greece had already entered the war on the allied side, and now Bulgaria and Rumania, both ethnically and historically linked to the great Slav state of Russia, overcame their fear of the Austro-Hungarian Empire and declared war on Turkey. Attacked on three sides, the Turks could make no stand and fell back towards the Bosphorous and Constantinople. But here the Allied fleets awaited them, with the Russian fleet steaming down the Black Sea to be 'in at the kill'. Against this multiple threat, severed from her allies, Turkey could offer no resistance, and the governing party, the Young Turks, sued for peace. The terms imposed were comparatively light: restoration of territory taken from Greece, Bulgaria and Rumania in the Balken Wars; demilitarisation of the Bosphorous and the Dardenelles; surrender of her armed forces, which after disarmament were demobilised, and allied armies of occupation along the Bosphorous and in the Vilayat of Basra.

With the signing of this peace treaty, all threat to the Near East and India vanished, and the war was confined to Europe. The Armies of Russia, Bulgaria, Rumania, Greece with expeditionary forces from France and the British Empire massed along the borders of the AustroHungarian Empire. Heavily outnumbered, with dissension in the ranks of the Hungarian armies, Austro-Hungary called upon her ally, Germany, for help. This was forthcoming but only at the expense of contracting her front in the Polish/Baltic States area. This in its turn relieved the pressure against Russia, severely mauled at the Battle of Tannenberg, allowing her to re-group and re-arm.

In the spring of 1916 a series of battles raged along the borders of Hungary and Bohemia, with the Italians pressing up from the South into Styria and the Tyrol. Outfought and outnumbered, the Austro-Hungarian forces everywhere retreated, and Germany, at life or death grip with France around Verdun, could do but little to help. The Emperor Franz Joseph died, and with his death the Holy Roman Empire crumbled and ceased to exist. Hungary seceded and sued for peace; the allied armies were everywhere along the borders of Austria and in the winter of 1916, she collapsed, leaving Germany alone and with her borders open to invasion from all sides. To prevent herself being overrun, in January, 1917,
Germany in her turn sued for peace. By the terms of the treaty signed by all the belligerent powers at the end of the same year, Germany handed back Alsace and Lorraine to France, and surrendered all her overseas territories save Tanganyika.

Early in 1918 things were beginning to return to normal. The Revolution in Russia was a mild affair. Being victorious, her armies fighting alongside their own kin, in constant contact with the West and little or no privation such as defeat would have brought, when the Tsarevitch died, as he did late in 1917, Tsar Nicholas II abdicated and a democratic government was formed, the Menshevicks easily outnumbering and outmanoeuvring the Bolshevicks.

And so peace came to the world again. Was Churchill so very wrong in his Dardenelles conception? If 'what might have been' is anywhere near correct, the answer must be 'No'.

In June, 1941, when the British Empire had been fighting Germany for eighteen months, the last twelve on her own, Hitler, in a megalomaniacal gesture, invaded Russia, so initiating what he himself would never allow to happen, making Germany fight simultaneously on two fronts. Winston Churchill, within 24 hours of the invasion, with an equally magniloquent gesture, called Russia a friend and ally, and pledged the British Empire to give her all the aid and help that lay within its power. And this pledge it honoured to the full, despite all the taunts, threats and insults thrown at it by its so-called ally. At the end, no thanks nor gratitude, not even common courtesy, at Yalta and Potsdam. So - if its object was merely to help defeat Germany - then Churchill's action succeeded, but it left Europe to the mercy - or lack of mercy — of the Russians; and the world, so far as armed might was concerned, divided between Russia and U.S.

\section{Was Churchill right to do as he did in 1941? Once again, let us consider what he might have done, and so, what might have been.}

When news of the invasion of Russia by Germany reached Churchill, he called an urgent meeting of the War Cabinet. At this it was decided to ignore this happening, so far as it wat possible to do so; to contain the conflict against Germany by British forces, but to offer no aid nor help to Russia. And to this policy, Churchill rigidly adhered, turning a deaf ear to all Russia's pleas for help. 
By the summer of 1942, German armies were deep into Russia, but Russian resistance was everywhere increasing. Sensing the attitude of the Allies towards Russia and anxious to try and defeat the latter before the onset of the next winter, Germany withdrew her forces from North Africa, the Allies taking no steps, either naval or military, to interfere with the operation, confining their activities to summarily defeating Italy on land and sea. At the same time they ceased to provoke Germany by offensive threats, thus silently encouraging her to send all her armed might Eastwards, which, as the struggle against Russia grew in fearful intensity, she increasingly did. By the summer of 1943 , the German armies had reached the Urals and taken the Crimea, but the Russians fought stubbornly, viciously and courageously along the whole front from the White to the Caspian Seas, and casualties on both sides reached catastrophic proportions. By mid-winter of that year, both countries had fought themselves to a standstill, both exhausted and impoverished in both men and material, both refusing to acknowledge defeat - and it was for this moment that the Allies had been waiting. In the early Spring of 1944, they invaded Europe.

Neither Germany nor Russia was capable of staging other than a token resistance, whilst those countries occupied by them in the previous decade, encouraged, aided and equipped by the Allies, rose, and in their turn defeated the occupying forces. The Nazi regime disintegrated and a democratic government, elected under the aegis of the victorious Allies, took over.

It took many months for the Allies to withdraw all the German troops and supply columns from Russia after the collapse; and relief supplies of every description and in enormous quantity was necessary to help the starving and distraught Russians. This help, the resultant penetration of the depths of Russia by outside agencies and personnel; and the consequent breaking down of the previous isolation of the Russian people from the outside world, caused the collapse of the already shattered and discredited Communistic regime, and the complete break up of the Union of Soviet Socialistic Republics. In its place there gradually evolved a number of more democratically governed independent states.

With Germany and Russia weakened to a degree from which it would take them generations to recover, Europe was once more at peace.

Once again one asks: was Winston Churchill wrong to take the action he did in 1941? If the foregoing bears any resemblance at all to what 'might have been', then the answer this time must surely be 'Yes'.

*Lt Col A. G. Johnson, MBE ED. 